\title{
Zerner, Monique (Org.) Inventar a heresia? Discursos polêmicos e poderes antes da Inquisição
}

Carlos Roberto Figueiredo Nogueira*

Campinas (SP): Ed. Unicamp, 2009. 304p.

After more than 30 years of study of the appearance of sects of 'evil worshippers,' which constituted the torment and the concern of the Church during the medieval period, methodically mapped and persecuted with increasing rigor until it culminated in the witch hunting of early modern Europe, one question became increasingly clear: in the construction of these sects, there existed a tragic combination, albeit effective from a repressive point of view, the amalgam of otherness with an enormous amount of erudition.

Thus, it is becoming ever more obvious to us that there was no estrangement or 'foreignness' in heretical sects. They were not beliefs which migrated and installed themselves within the heart of good Christians, nor were they 'survivors of a paganism' which had been lost for a long time and of which all that is left are fragmented and unrooted symbols or remains of a clearly Christianized gestuality. Rather it was the product of the intentions of an orthodoxy to impose on others the existence of other interpretations of what it was to live (spiritually and materially) the Christian religion.

Christianity was born as a religion which proposed to be universal in a world of particularities, especially religious particularities. To bring the Good News to all men, Christianity needed to impose itself on the Other.

Thus the ecclesia was constructed, first breaking away from Judaism, the first and most bothersome 'other' due to its proximity and the responsibility of having gestated a new religiosity.

Once the 'murderers of Christ' were eliminated, the disaffected and oppositions, in short the heterodox, were silenced or persecuted, objects of an erudite recovery which dived deep into Classical Antiquity to look for identities, establish connections to guarantee credibility, and to legitimate repression.

In this way the 'folkloric reaction' to pagan survivals, the creator of heresy,

^Professor Titular, Universidade de São Paulo. Av. Lineu Prestes, 338 - Cidade Universitária. 05508-000 São Paulo - SP - Brasil.crfnogue@usp.br 
change meaning. Paganism wins the right to exist through the intermediation of the action of an orthodoxy in search of a tradition which will allow it establish parallel and impose labels on rivals.

It is with grateful surprise that we see here in the Brazilian market the public organized by Monique Zerner: "Inventing Heresy?"

A plural work, but with a singular internal cohesion: the analysis of the treatises which construct heresy and 'identify' the heretic. The product of investigations produced and discussed in seminars, in our opinion it correctly returns to the texts written before the creation of the Tribunals of the Inquisition. A correct posture, since if the objective was to confront the documents with the 'reality' of heresies, the period of inquisitorial action would involve enormous problems, because the persecution involves consecrating the heresy ipso facto, making it an irreversible reality, whose punishment presents to the community its objective and unquestionable materialization. An addictive reality which led many historians to believe in the reality of heresies, or even imagine them as another religion, as in the case of Catharism.

Inventar a Heresia? covers a large temporal trajectory, beginning with St. Augustine and his proceedings in the polemics with Manichaeism with which he had become disenchanted and extending to a case of non-heresy in Gascony at the beginning of the twelfth century.

And why such a wide interval of time? The answer is found in the authors' perspective. We know that at the beginning of Christianity the tonic was persuasion. Nevertheless, in Contra Faustum St. Augustine already prefigured the attitude which will come afterwards - if not persuaded adversaries would in the end be condemned.

From the Manichaeists and Greek exegetas from the Bible the work jumps to the eleventh century, the period of the emergence of heresies, a moment which Jacques Le Goff has mistakenly read as a folkloric resurgence, which justifies the appearance of heretic movements.

The work we are examining inverts the question, looking within the conflicts at a church which sought to impose its reformist hegemony, the 'manufacturing' of heretics. Heresy was used by Gerardo in the Synod of Arras as a response to his attempt to maintain control over a dominion which was slipping through his fingers as it was related to an antiquated Carolingian system unable to take account of the new social order.

However, this argument persisted with Peter the Venerable and his Contra Petrobrusianos. Nevertheless, it is singular that this abbot of Cluny invested 
against heretics, Jews and the Saracens. The eleventh century and fundamentally Cluny were preparing weapons to defend the Church. The 'defensive' argument of this abbot does not resist a policy of the hegemony of religiosity. At the end of the eleventh century, the path to the absence of dialogue with heresy was opened, replaced by judicial proceedings to make those whom the Church condemns confess the truth.

The offensive intensified. The increasingly wider front, the ever more irreducible enemy. With the incorporation of Roman Law in Cannon Law, and the establishment of the crime of lese-majesty in the thirteen century, it ended up being necessary to appeal to arms against heretics, whose emblematic example was the Albigensian Crusade.

"But who are the heretics?" asks Michel Lauwers, seeking heretics in the social tensions and (the contestations of privileges and ecclesiastical terminations) and analyzes as a example the question 'Does the suffering of the living benefit the dead?" where he demonstrates how controversialists moved from the refusal of practices imposed by the institution to doctrine, making this an instrument of the judgment of refusal: heresy.

"Albigenses: Observations about a denomination", whose unpretentious title hides its real contents, is by far the high point of the collection. Here JeanLouis Biget identifies and analyzes the history of the name Albigenses, protagonists of a history which began in 1209, but which was brusquely 'forgotten' after 1960, being replaced by 'Cathars.' For this he returns to the role of the Cistercian order as the constructor of heresy. Committed to consolidating the reform of the Church, it translated the internal and regional conflicts which compromised the desired unity as the expression of doctrinal divergences. In other words, from the invention of a name to baptize the deviants from the true unity to the designation of all the religious dissidents of the Midi.

As noted by Dominique Iogna-Prat the lack of analyses of anti-heretical discourses is striking even in our day. Works about heresy analyze documents as sources which express the heretical reality and not as a discourse constructed through the constitutional lens.

This book teaches us a fundamental principle. In relation to documents which deal with heresy the reality of the facts described by the texts produced in an ecclesiastical text or by authors linked to it have to be doubted. In his afterword R. I. Moore goes further: "not even in a movement not covered and relatively innocent of the enthusiasm for the vita apostolica entre rustici." The accusation of heresy became the principal tool for the construction of unity, 
coating in a 'sacred aura' the much less momentous task in the eyes of the Christian community of eliminating deviations and keeping the Christian flock within the orthodoxy proclaimed as religious, but whose real threat was not in the sacred plane, but in the political and social divergences which threatened the ecclesiastic institution.

There is only one criticism, which does not fundamentally compromise the quality of the work. The translation of the chapters, albeit done in a correct manner, suffers from the fact that it was done by distinct collaborators, which means that the style of the text varies, sometimes more fluid and sometimes more stilted. However, I repeat that this only affects the aesthetic, not the content of the chapters.

We cannot end without looking at a small, but no less important chapter (highly clarifying of the rigorous nature of this collection) which establishes at the end of the work a precious counterpoint: "A case of non-heresy in Gascony in the year of 1208." In light of a 'revolution' of lay dependents de Saint Sever in Gascony the papal legate inverted roles, ignored certain practices and made a non-heretical reading of the episodes (extremely necessary due to the crisis which was established between Innocence III and John I of England, who held dominion over the insurgent lands). Here we have a good demonstration of the exception which confirms and elucidates the rule!

We have here instigating articles which open doors to the doubting and questioning of the construction of heresy. Which leads us to end this review assuming as ours the words of the author Benoit Cursente, who sums up the perspective of all the authors of Inventar a heresia?: "And in these circumstances, for heresy not to exist, it was sufficient and necessary not to name it."

Review received on October 10, 2011. Approved on December 3, 2011. 